УДК:94(438+477)

\title{
LAW ENFORCEMENT STRUCTURES AS A PART OF NATIONAL POLICY CONCERNING JEWISH POPULATION IN GALICIA IN INTERWAR POLAND
}

\author{
Ivan FEDYK \\ Ivan Franko National University of Lviv \\ Department of Local History \\ Universytetska str. 1, Lviv, 79000, Ukraine \\ e-mail: vanofedyk@yahoo.com
}

\begin{abstract}
Using the documents of police and attorney departments the author of the article tried to make general analysis of state national policy in Galicia concerning Jewish population of Poland between the two world wars and the participation of law enforcement agencies in this policy. Of all the territories of interwar Poland, Galicia had the largest Jewish population. In 1921, there were 736,000 Jews recorded there, and in the Lviv region there were 313,206 people, and in Lviv in 1921 there were 78,854 Jews, most of all from the cities of Galicia. Before the war, Jews ranked second in terms of population in this city, only being less than the Poles.

The Jewish side of the national policy of the Second Polish Republic had its differences in comparison with the relations of the Polish authorities and other peoples who lived in this state. Very often, law enforcement agencies tried not only to limit some anti-Polish sides of the Jewish movement, but also to block anti-Jewish phenomena, which often occurred in this controversial society.

After the war, the Jews received some positive acts from the Polish authorities. In response some of the Jewish leaders called on the Jewish population of Poland to move to neutrality, or to support the actions of the authorities. Among the intellectuals in postwar Poland was a large stratum of Jews, also they were among the large and middle bourgeoisie, bankers and financiers, who sponsored significant part of Jewish organized life, including the departure to the historical homeland of Palestine. At the same time, the Lviv Police Department of the State Police actively supervised and observed the activities of all Jewish organizations. Political and social actions of Jews were often banned, and criminal cases against their organizers were opened.

As evidenced by archival documents, all Jewish political parties, national-cultural, religious communities and their leaders, in particular, were under the watchful eye of the Polish State Police. In addition, there are a lot of documents in the funds of the State Archives of Lviv Region concerning the persecution of Jews by Polish political groups and organizations. However, law enforcement agencies have often acted against such groups, protecting the Jewish population.

Keywords: Poland, Jews, police, prosecution, Galicia.
\end{abstract}

Interwar Poland was formed as a multinational state, and, in addition to the Poles, it was formed by Ukrainians, Jews, Belorussians, Germans, Lithuanians, Czechs and other nationalities, smaller in number.

As you know, as a result of the victory in the Ukrainian-Polish war and the decision of the Council of the Ambassadors of the Paris Conference-Eastern Galicia, Western Volhynia and other Ukrainian lands were transferred to the Second Republic of Poland. As a result of the decisions of the same Paris conference, Poland received part of the 
ISSN 2078-6077. Наукові зошити історичного факультету Львівського університету. 2018-2019. Випуск 19-20. Proceedings of History Faculty of Lviv University. 2018-2019. Issue 19-20.

former German territory in Silesia, according to the Munich Agreement; After the Polish-Lithuanian war and the Suwal Agreement, Vilnius and a part of the Lithuanian territory remained.

A large number of Jews lived in these newly-affiliated territories, which, having joined the Polish state, significantly increased the number of their fellow-believers in ethnic Poland ${ }^{1}$.

At the beginning of the rebirth of the Polish state there were 3 million Jews, that is, about $10 \%$ of the total population of the country, and they had a civil right guaranteed by the 1921 Constitution. In 1919 Jews were recognized as a national minority ${ }^{2}$.

Of all the territories of interwar Poland, Galicia had the largest Jewish population. In 1921, there were 736,000 Jews recorded there, and in the Lviv Voivodship there were 313,206 people, and in Lviv in 1921 there were 78,854 Jews, most of all from the cities of Galicia. Before the war, Jews ranked second in terms of population in this city, only being less than the Poles ${ }^{3}$.

In general, in post-war Poland, Jews were second in number after the Ukrainians as a national minority.

During the Ukrainian-Polish war of 1918-1919, in particular during the battles for Lviv, one of the events event became the determinant of relations between the Polish authorities and the Jews in the 1920s. This event was partially a blow to the Jewish population of Galicia for their neutrality in the attitude to the Ukrainian authorities in the province, as well as their participation in battles against the Polish army on the side of the Ukrainian Galician Army. As a result, there were pogroms in Lviv, committed by the soldiers of the Polish Army in late November 1918, when 73 Jews died and 433 were seriously wounded, more than five thousand families were robbed, several dozen buildings burned down ${ }^{4}$. The attitude of the military was partially extrapolated onto the Jewish-Polish relations in the years to come. Therefore, law enforcement structures often started investigations against Jewish political bodies basing on possibilities rather than on suspicion.

After the war, as already mentioned above, Jews received some positive acts from the Polish authorities. In response, some Jewish leaders called on the Jewish population of Poland to move to neutrality, or to support the Polish authorities. Subsequently, the political, national and cultural life of the Jewish minority began to develop more quickly, despite certain obstacles of political nature. According to estimates of prof. Melamed there turned out to be 22 Jewish periodicals published in Polish in Lviv during the interwar period. During the elections to the Polish Parliament, Jews received $8 \%$ of the mandates, which is much larger than any other national

\footnotetext{
${ }^{1}$ Г. Дильонгова, Історія Польщі 1795-1990. (Київ: Видавничий дім “Києво-Могилянська академіяо, 2007), 122-123.

${ }^{2}$ Ibid., 121.

${ }^{3}$ В. Меламед, Евреи во Львове. ХІІІ - первая половина ХХ века. События. Общество. Люди. (Львів: Текоп), 238-239.

${ }^{4}$ Микола Литвин, Украӥнсько-польська війна 1918-1919 рр.,(Львів, 1998), 98-99.
} 
minority in the country ${ }^{5}$. Yet despite the persecution, Jews were more tolerated by the new government than, for example, Ukrainians or Belorussians, although antiSemitism in the inter-war Poland was quite high.

One of the reasons is that other minorities struggled for the restoration or creation of their own states, considering the Polish authorities as occupational ones. Moreover, some Ukrainians and Belorussians favored the movements for the reunification of their lands with the Soviet republics of the USSR. The struggle for national reunification was also a slogan of Lithuanians and Germans.

In the Jewish political and national-religious environment, the situation was different.

Politically, Jews in Poland were divided into three groups: the first is the Zionists, who advocated the unification of all Jews, for emigration to Palestine and the establishment of their own state there. The Polish authorities, especially the National Democrats, tried to control their activities on the one hand, and on the other, they contributed to their emigration movement, denying the struggle of the Jews for their autonomy.

The second part of the Jews, who were active members or supporters of the Bund and advocated the realization of socialist ideas, had significant problems with the Polish authorities and law enforcement structures, especially during the rule of National Democrats. However, the most followed by the law enforcement in the interwar Poland were those Jews who belonged to the Communist Party.

The third movement or group was the "Union of Israelî, which defended Jewish traditions, fought to preserve the Jewish spirit in the internal life of the Jewish community in Poland .

It should be noted that there were no interethnic conflicts in inter-war Poland, especially among national minorities, that there was no conflict between Jews and other subjugated nations, with the exception of certain economic misunderstandings at the domestic level among the marginal elements. Only in the late 1930s, especially in the German community of Poland under the influence of Nazi propaganda in Germany, the interethnic situation began to change not in favor of the Jews.

Many problems for the Jewish environment in Poland were brought by the work of those Jews who joined or were activists in the communist movement, which was known to have been controlled and directed in its activities by the Soviet Union. As a result law enforcement paid constant attention to socialist Jewish parties and organizations trying to find the connection with communists or Soviets.

Of all the Polish political forces, the Polish right-wing politicians took the most rigid stance towards Jewry and its political and cultural environment. The inclusive conference of the National Democrats concerning the national minorities in Poland did not give much encouragement to the Jews for the development of their national

\footnotetext{
${ }^{5}$ В. Меламед, Евреи во Львове. ХІІІ - первая половина ХХ века. События. Общество. Люди. (Львів: Текоп), 256-264.

${ }^{6}$ Г. Дильонгова, Iсторія Польщі 1795-1990. (Київ: Видавничий дім “Києво-Могилянська академія о, 200, 122.
} 
ISSN 2078-6077. Наукові зошити історичного факультету Львівського університету. 2018-2019. Випуск 19-20. Proceedings of History Faculty of Lviv University. 2018-2019. Issue 19-20.

life. Therefore, in many cases, the Jewish deputies of the Polish Parliament spoke with representatives of the Ukrainians and Belorussians against the policies of the Polish governments and the actions of Polish police ${ }^{7}$.

As written in archival documents, all Jewish political parties, national-cultural, religious communities and their leaders, in particular, were under the close watch of the Polish State Police. There were lists of Jewish activists, and not only Jewish, police investigators recorded all the old and newly created organizations, secret agents were present at any of the events that were organized by Jewish community ${ }^{8}$.

The Lviv Police Department of the State Police actively supervised and observed the activities of the Zionist organizations considering them dangerous to the Polish state ${ }^{9}$.

Even minor actions of Jewish representatives were either forbidden, or against their organizers were opened criminal cases. Thus, the prosecutor of the district court in Lviv instituted a criminal case against the Jews, in particular, against Leiba Abram Zilberman and his comrade Somet Satupen for the distribution of leaflets against the consumer organization Trumfeldor, although, there was no threat to the state there. ${ }^{10}$ There have often been cases when the prosecutor's office or courts defended the Jews, especially if the case was against the Ukrainians and thus the authorities tried to organize Jewish-Ukrainian misunderstandings or conflict. For example, the prosecutor of the district court in Lviv opened a criminal case against the fact that the Ukrainian nationalists boycotted the state tobacco monopoly, represented by the Jew Israel Muter ${ }^{11}$. A criminal case was opened against Ukrainian nationalists who were accused of anti-Jewish speeches ${ }^{12}$.

On the other hand, Polish prosecutor's office and the courts tried to stop or to turn away anti-Jewish acts in the course of their activities, but for the most part, the perpetrators received only light warnings ${ }^{13}$. Thus, in 1937, a criminal case was opened against two Polish extremists - Kazimir Podgalig and Juzef Ruzhitsky, who were accused of anti-Jewish activities, but, in the absence of evidence, they both were acquitted. In Poland, as well as in the "Eastern Crests", there were many instances of prosecution against students for anti-Semitism. Significant is the criminal case opened in 1937 against Sigmund Mikhalievich and Tadeusz Vengzyniak for beating Jewish students ${ }^{14}$. Some Yan Khmara was accused of causing damage to Nelson's Scale on the basis of anti-Semitism ${ }^{15}$. The case of beating Jewish students by Polish

\footnotetext{
${ }^{7}$ К. Пальківський, “Народи Галичини в історичній перспективі,” Листи до приятелів, №.145146, Кн. 3-4, 1965, 34-40.

${ }^{8}$ Державний архів Львівської області, фонд 108, опис 1, справа 558. арк.. 1-3.

9 Державний архів Львівської області, фонд 108, опис 1, справа 571. арк. 1.

${ }^{10}$ Державний архів Львівської області, фонд 139, опис 9, справа 267. арк. 1-3.

${ }^{11}$ Державний архів Львівської області, фонд 139, опис 9, справа 743. арк. 1-3.

12 Державний архів Львівської області, фонд 139, опис 9, справа 747. арк. 3.

13 Державний архів Львівської області, фонд 139, опис 9, справа 2476. арк. 7.

${ }^{14}$ Державний архів Львівської області, фонд 139, опис 9, справа 2408. арк. 1.

${ }^{15}$ Державний архів Львівської області, фонд 139, опис 9, справа 2410. арк. 1.
} 
students at Lviv University was considered one of the most important ones, as well as a similar criminal case for the beating of Jewish students in Lviv Polytechnic. Among those who were beaten were students Adolph Wasser, Karol Vrunvasser and Mayer Whitlinn ${ }^{16}$. In these actions, students were often subjected to Polish youth organizations. For example, on the basis of anti-Semitism, students and other representatives of the youth attacked David Lyandau and Anna Lyandau, peacefully walking on Lviv Street ${ }^{17}$. Mlodzjerz Vszechpolska was the organizer of many antiJewish performances and pogroms. For example, they often threw inflammatory devices into jewelry stores or destroyed property inside. The rigid reaction of the authorities to such actions is evidenced by the case of Max Feder, whose store was destroyed in 1934 by an explosive device ${ }^{18}$. All Polish organizations and movements that demonstrated anti-Semitic behavior were supported by the majority of Polish community as patriotic youth groups, although, law enforcement periodically organized arrests of those who performed violent actions against Jewish people.

In general, law enforcement agencies responded in a timely manner to intolerance towards the Jewish population of the region, which caused many moderate Jews, in particular from the environment of Agudat Israel, to feel an extent of security brought from the part of the authorities, and therefore they clearly respected the power and demonstrated loyalty to the Polish state. By the way, many Jews used the Polish language even in their everyday life, published their print media in Polish and studied Polish in their schools. More radical Jewish political environment that fought for the provision of all civil rights to the Jewish people in Poland, advocated the preservation of their identity, which had often been the subject of pressure from the police and the prosecutor's office. The censorship of their press was more rigorous, investigative cases against their leaders - more bulky, sometimes searches were subjected to offices of organizations or educational institutions ${ }^{19}$. Thus, in 1933, the Jewish newspaper "Khvylia Volynska" was confiscated for criticism of the authorities ${ }^{20}$. The same was repeatedly done with the "Morgen" newspaper, which went out on Yiddish" This shows that Polish law enforcement structures had different aproacu to various Jewish political groups depending on their activity and participation in political life.

Unlike other countries in that time, Jewish pogroms in interwar Poland were not a frequent occurrence, but cases of attacks on stores where Jews were owners were frequent. At the same time, law enforcement agencies tried to hide information about it - for the publication of material about pogroms and attacks on Jews, the newspaper could be immediately confiscated. This was the case with Jewish newspapers "Dos

\footnotetext{
${ }_{16}$ Державний архів Львівської області, фонд 139, опис 9, справа 2414, арк. 1-5.

${ }^{17}$ Ibid, спр. 2417, арк. 2.

${ }^{18}$ Ibid, спр. 1494, арк. 1-4.

${ }^{19}$ Ibid, спр. 1496, арк. 1-28.

${ }^{20}$ Ibid, оп. 5, спр. 640. арк. 1-3.

${ }^{21}$ Ibid, спр.144. арк. 1.
} 
ISSN 2078-6077. Наукові зошити історичного факультету Львівського університету. 2018-2019. Випуск 19-20. Proceedings of History Faculty of Lviv University. 2018-2019. Issue 19-20.

Fraje Wort"22, "Arbeiter Sztyme"23, and "Unzer Weg". ${ }^{24}$ On the other hand, such a censorship demonstrates the wish of Polish authorities to show themselves as ethically tolerant power.

The state police paid a lot of attention to the Jewish socialist movement, which advocated the improvement of the lives of Jews, called for national and social justice, and eventually the creation of a Jewish autonomy in Poland. Already in 1924, the Jewish parties Bund and Paoley Zion found themselves under increased police surveillance, which was reported to the Lviv District government and Lviv Provincial Directorate ${ }^{25}$. Even the work of educating children, as well as the activities of Jewish youth organizations, was under the constant supervision of the state police. In 1921, the police organized surveillance of the IV National Congress of Jewish organizations of working youth "Zukunft", as well as overseeing the activities of the "Our Children" Society and Scout Organization "Gamoar Gazioni"

Another feature of the work of law enforcement agencies in the area of Jewish problems was the surveillance of those persons who returned or left for Poland from the Soviet Union or Germany. Every permit was carefully checked by the police ${ }^{27}$. It was done because these two countries were considered to be hostile to Poland and the law enforcement tried to avoid allowing international spies enter the territory of the Second Polish Republic.

All this was the only picture of the inappropriate attitude towards the Jewish population on the part of power, which gave rise to various extremist organizations to organize anti-Jewish actions ${ }^{28}$. This, in turn, caused indignation among various sections of the population of Poland, which often transcended into protest actions, in which representatives of various strata of the population and different nations participated ${ }^{29}$. An example is the big strike that took place in Lviv on March 17, 1936 in protest against Jewish pogroms ${ }^{30}$.

In addition, deputies-representatives of Jewish organizations in the Polish Parliament had consistently inquired about the negative phenomena in Poland, in particular in Galicia. Back in 1919, a request from the Jewish National Club of Sejm Deputies in connection with the arrest without serious reasons of Jews in Lviv came to the Police Directorate in Lvivis.

22 Державний архів Львівської області, фонд 11, опис 29, справа 5826. арк. 1-14.

23 Державний архів Львівської області, опис 29, справа 2847. арк. 1-11.

24 Державний архів Львівської області, фонд 11, опис 2843, справа 1496. арк. 1-14.

25 Державний архів Львівської області, фонд 7, опис 4, справа 98. арк. 1-2.

${ }^{26}$ Державний архів Львівської області, фонд 108, опис 1, справа 577. арк. 1-4.

${ }^{27}$ Державний архів Львівської області, фонд 123, опис 1, справа 428. арк. 1-4.

${ }_{28}^{2}$ Державний архів Волинської області, фонд 46, опис 9, справа 142. арк. 1-2.

29 Державний архів Волинської області, фонд 46, опис 9, справа 389. арк. 26.

${ }^{30}$ Історія Львова в документах та матеріалах. Збірник документів і матеріалів. (Київ: Наукова думка, 1986), 197.

31 Державний архів Львівської області, фонд 271, опис , справа 450. арк. 1-2. 
A separate phenomenon in the system of relations of "power-citizen" was the attitude of law-enforcement bodies to Jewish communist environments, as well as those Jews who participated in radical left-wing organizations of other nations. The reason for this was that the Communists openly called for the overthrow of the Polish government, the joining of the eastern territories to the USSR, and organized strikes, especially during the economic crisis, demonstrations, secretly publishing newspapers and leaflets. The Polish government believed that the communists were ruled by Moscow. ${ }^{32}$ Therefore, law enforcement used harsher punitive measures against them. In the end, the participation of many Jews in the communist movement was to some extent compromised by the activities of the Jewish national movement, whose leaders tried to separate from them. Often, the very suspicion of communist activity could be the reason for the opening of an investigative case ${ }^{33}$. There were even executions, as in the case of Naphthal Bottwin on August 6,1926 $6^{34}$, or deportations, as in the case of the Leisor-Mendel ${ }^{35}$.

In general, the Jewish side of the national policy of the Second Polish Republic had its differences in comparison with the relations of the Polish authorities and other peoples who lived in this state. Very often, law enforcement agencies tried not only to limit some anti-Polish sides of the Jewish movement, but also to block anti-Jewish phenomena, which often occurred in this controversial society. Much of the Jewish population in Poland was loyal to the Polish government. The Jews had a fairly respectable representation in the Polish parliament. Although Poland was a state of limited democracy, national minorities, including Jews, broadly developed their national life. In addition to a large number of parties and civic organizations in Poland, there were hundreds of religious, humanitarian and various kinds of help organizations, schools and religious institutions. Among the intellectuals in post-war Poland was a significant stratum of Jewish intellectuals. The political and social environments included many bankers and financiers who sponsored significant amounts of Jewish political, national and cultural life, as well as visits to their historic Motherland, Palestine.

${ }^{32}$ W. Pobog-Malinowski, Najnowsza Historia Polityczna Polski. 1864-1945. (Londyn, 1956), T. II, 562-563.

${ }_{33}$ Державний архів Львівської області, фонд 271, опис 1, справа 66. арк. 1-11.

${ }^{34}$ Історія Львова. (Київ: Наукова думка, 1984), 195.

${ }^{35}$ Державний архів Львівської області, фонд 123, опис 1, справа 434. арк. 1-7. 
ISSN 2078-6077. Наукові зошити історичного факультету Львівського університету. 2018-2019. Випуск 19-20. Proceedings of History Faculty of Lviv University. 2018-2019. Issue 19-20.

\title{
ОРГАНИ ПРАВОПОРЯДКУ ЯК ЧАСТИНА НАЦІОНАЛЬНОЇ ПОЛІТИКИ МІЖВОЄННОЇ ПОЛЬЩІ ЩОДО ЄВРЕЙСЬКОГО НАСЕЛЕННЯ В ГАЛИЧИНІ
}

\author{
Іван ФЕДИК \\ Львівський національний університет імені Івана Франка \\ Кафедра історичного краєзнавства \\ вул.Університетська 1, Львів, 79000, Україна \\ e-mail: vanofedyk@yahoo.com
}

Під час польсько-української війни 1918-1920рр. багато євреїв Галичини підтримали українців у їхній боротьбі за свою державність. Деякі з них боролися в лавах Української Галицької Армії, зокрема єврейський курінь бився за Тернопіль, а деякі євреї, як от Сальцьо Ротенберг i Карл Бельке, віддали своє життя за Україну. Після опанування поляками Львова, у місті польські вояки вчинили кривавий єврейський погром, як помсту за допомогу украӥнцям і наприкінці листопада 1918 року у Львові загинуло 73 євреї, 433 було важко поранено, більше п’яти тисяч сімей пограбовано, горіли єврейські квартали і крамниці. Після закінчення війни євреї отримали від польської влади деякі преференції. У відповідь частина їхніх лідерів закликала своїх співвітчизників у Польщі перейти до нейтралітету або ж підтримати дії влади. За підрахунками професора Меламеда у Львові в міжвоєнний період виходило 22 єврейські періодичні видання польською мовою. Під час виборів до польського парламенту євреї отримали $8 \%$ мандатів набагато більше, ніж будь-яка інша національна меншина країни. Серед інтелігенції в повоєнній Польщі був значний прошарок євреїв, також вони були серед великої і середньої буржуазії, банкірів та фінансистів, які спонсорували великі суми на організацію свого національного життя, а також і на виїзд до історичної Батьківщини - Палестини. При цьому Львівська повітова управа державної поліції активно вела нагляд і слідкувала за діяльністю всіх єврейських організацій. Політичні та соціяльні акції євреїв були часто заборонені, а проти їх організаторів відкривали кримінальні справи.

Як засвідчують архівні документи, всі єврейські політичні партії, національно-культурні організації, релігійні середовища та ї лідери, зперебували під пильним і постійним наглядом польської державної поліції. Крім того, у фондах Державного архіву Львівської області $є$ чимало документів, які стосуються переслідування євреїв польськими політичними групами та організаціями. Однак, органи правопорядку часто діяли проти таких середовищ, захищаючи єврейське населення.

Ключові слова: Польща, євреї, поліція, слідство, Галичина.

\section{REFERENCES}

Derzhavnyy arkhiv L'vivs'koyi oblasti, fond 108, opys 1, sprava 558. ark. 1-3. Derzhavnyy arkhiv L'vivs'koyi oblasti, fond 108, opys 1, sprava 571. ark. 1. Derzhavnyy arkhiv L'vivs'koyi oblasti, fond 108, opys 1, sprava 577. ark. 1-4. Derzhavnyy arkhiv L'vivs'koyi oblasti, fond 11, opys 2843, sprava 1496. ark. 1-14.

Derzhavnyy arkhiv L'vivs'koyi oblasti, fond 11, opys 29, sprava 5826. ark. 1-14.

Derzhavnyy arkhiv L'vivs'koyi oblasti, fond 123, opys 1, sprava 428. ark. 1-4. Derzhavnyy arkhiv L'vivs'koyi oblasti, fond 123, opys 1, sprava 434. ark. 1-7. Derzhavnyy arkhiv L'vivs'koyi oblasti, fond 139, opys 5, sprava 144. ark. 1. Derzhavnyy arkhiv L'vivs'koyi oblasti, fond 139, opys 5, sprava 640. ark. 1-3. 
ISSN 2078-6077. Наукові зошити історичного факультету Львівського університету. 2018-2019. Випуск 19-20. Proceedings of History Faculty of Lviv University. 2018-2019. Issue 19-20.

Derzhavnyy arkhiv L'vivs'koyi oblasti, fond 139, opys 9, sprava 1494. ark. 1-4.

Derzhavnyy arkhiv L'vivs'koyi oblasti, fond 139, opys 9, sprava 1496. ark. 1-28.

Derzhavnyy arkhiv L'vivs'koyi oblasti, fond 139, opys 9, sprava 267. ark. 1-3.

Derzhavnyy arkhiv L'vivs'koyi oblasti, fond 139, opys 9, sprava 2476. ark. 7.

Derzhavnyy arkhiv L'vivs'koyi oblasti, fond 139, opys 9, sprava 2408. ark. 1.

Derzhavnyy arkhiv L'vivs'koyi oblasti, fond 139, opys 9, sprava 2410. ark. 1.

Derzhavnyy arkhiv L'vivs'koyi oblasti, fond 139, opys 9, sprava 2414. ark. 1-5.

Derzhavnyy arkhiv L'vivs'koyi oblasti, fond 139, opys 9, sprava 2417. ark. 2.

Derzhavnyy arkhiv L'vivs'koyi oblasti, fond 139, opys 9, sprava 743. ark. 1-3.

Derzhavnyy arkhiv L'vivs'koyi oblasti, fond 139, opys 9, sprava 747. ark. 3.

Derzhavnyy arkhiv L'vivs'koyi oblasti, fond 271, opys , sprava 450. ark. 1-2.

Derzhavnyy arkhiv L'vivs'koyi oblasti, fond 271, opys 1, sprava 66. ark. 1-11.

Derzhavnyy arkhiv L'vivs'koyi oblasti, fond 7, opys 4, sprava 98. ark. 1-2.

Derzhavnyy arkhiv L'vivs'koyi oblasti, opys 29, sprava 2847. ark. 1-11.

Derzhavnyy arkhiv Volyns'koyi oblasti, fond 46, opys 9, sprava 142. ark. 1-2.

Derzhavnyy arkhiv Volyns'koyi oblasti, fond 46, opys 9, sprava 389. ark. 26.

Dyl'onhova H., Istoriya Pol'shchi 1795-1990. (Kyyiv: Vydavnychyy dim "KyyevoMohylyans'ka akademiya", 2007).

Istoriya L'vova $v$ dokumentakh ta materialakh. Zbirnyk dokumentiv i materialiv. Kyyiv: Naukova dumka, 1986.

Lytvyn, Mykola. Ukrayins 'ko-pol's'ka viyna 1918-1919 rr., L'viv, 1998.

Melamed, V. Evreyi vo L'vove. XIII - pervaya polovyna XX veka. Sobytyya. Obshchestvo. Lyudy. L'viv: Tekop.

Pal'kivs’kyy, K. , "Narody Halychyny v istorychniy perspektyvi,” Lysty do pryyateliv, №.145146, Kn. 3-4, 1965.

Pobog-Malinowski, W. Najnowsza Historia Polityczna Polski. 1864-1945. Londyn, 1956. T. II. 